\title{
Drought Induced Fine Root Growth and Canopy Green-up of Tropical Dry Zone Vegetations in Sri Lanka
}

\author{
K. A. J. M. Kuruppuarachchi ${ }^{1 *}$, G. Seneviratne ${ }^{2}$ and B. D. Madurapperuma ${ }^{3}$ \\ ${ }^{1}$ Department of Botany, The Open University of Sri Lanka, Nawala, Nugegoda, Sri Lanka \\ ${ }^{2}$ Microbial Biotechnology Unit, Institute of Fundamental Studies, Kandy, Sri Lanka \\ ${ }^{3}$ Environment and Conservation Science Program, North Dakota State University, P. O. Box 6050, \\ Fargo, ND58108, USA
}

Date Received: 24-11-2012 Date Accepted: 18-02-2013

\begin{abstract}
Fine roots in forest soils have important implications for global carbon (C) balance, but processes underlying this $\mathrm{C}$ sink are not well understood. This study evaluates year round dynamics of fine roots in a tropical dry mixed evergreen forest and an arboretum in the dry zone of Sri Lanka. Monthly soil core samples (up to $25 \mathrm{~cm}$ depth) were collected randomly to cover a whole annual cycle of the two sites. The soils were air dried, sieved $(<2 \mathrm{~mm})$, and fine roots $(\leq 2 \mathrm{~mm})$ were separated by handpicking coupled with a water floating technique. Then, fine root biomass and $\mathrm{C}$ density were calculated using oven dry weight. Annual mean fine root biomass of the dry zone forest and the arboretum were found to be $5.72 \pm$ $0.57 \mathrm{t} / \mathrm{ha}$ and $7.88 \pm 0.81 \mathrm{t} / \mathrm{ha}$, respectively, with $\mathrm{C}$ densities of $2.69 \pm 0.27 \mathrm{t} / \mathrm{ha}$ and $3.7 \pm 0.38 \mathrm{t} / \mathrm{ha}$, respectively. Thus, dry zone arboretum showed a higher growth and biomass, and hence a $\mathrm{C}$ pool of fine roots, than the dry zone forest, possibly due to a younger forest stand with fast fine root turnover rate. In both sites during the dry spell, there was an increased production of fine roots and a simultaneous leaf flush on the canopy with a green-up. The increased fine root growth during the dry season generally allows the trees to absorb more water under water-stressed situations. These events may be due to an undisclosed survival mechanism of such ecosystems under drought, which needs further studies.
\end{abstract}

Key words: Drought, Fine root growth and canopy green-up, Tropical dry zone vegetation

\section{Introduction}

Fine roots (diameter $<2 \mathrm{~mm}$ ) have important implications for the global $\mathrm{C}$ balance, but the processes underlying this $\mathrm{C}$ sink are not well understood (Vargas and Allen, 2008). Although fine roots represent only a small fraction (ca. 5\%) of the total tree biomass, they can consume about 30 to $50 \%$ of the annual primary production (Jackson et al., 1997) and are a major contributor to organic matter and mineral nutrient cycles. Other functions of fine roots include anchorage, absorption of water, and synthesis of various essential compounds such as growth regulators (Upadhaya et al., 2005).

*Correspondence: kajmkuruppu@gmail.com

Tel: +94 (011) 288 1269; Fax: +94 (011) 2436858

ISSN 2235-9370 Print / ISSN 2235-9362 Online (C2013 University of Sri Jayewardenepura 
Fine roots, existing as a root mat in the surface soil, are a common feature of tropical forests. They act as a safety net for conserving soil nutrients (Seneviratne et al., 2006). Fast growth and turnover of fine roots make the fine root system a dynamic component of the forest $\mathrm{C}$ cycle (Rasse et al., 2005). Fine root biomass is an important parameter related to $\mathrm{C}$ allocation and turnover at the ecosystem level (Jackson et al., 1997; Nepstad et al., 1994). Jackson et al. (1997) estimated that globally, about 20 Gt C is stored in living fine roots. About $30 \%$ of that is contained within tropical forests. Factors such as soil temperature, moisture, and nutrient availability control growth and turnover of fine roots (Pregitzer, 2002). Hence, forest floor litter accumulation plays an important role in growth and turnover of fine roots. Therefore, there is an annual pattern of fine root dynamics that regulates soil $\mathrm{C}$ turnover and sequestration. To understand soil $\mathrm{C}$ sequestration of the forest ecosystems, it is thus necessary to conduct detailed studies of fine roots with extensive sampling.

The dry zone of Sri Lanka represents $80 \%$ of its land mass (Perera, 2001). Eighty percent of the dry zone is covered by forests, which are called "secondary old climax vegetations" or "dry mixed evergreen forests" (Dittus, 1985). Thus, the dry zone plays an important role in the C sequestration. However, there are no proper studies conducted to investigate fine root dynamics in the dry zone. Therefore, the present study was planned to examine the annual growth pattern of fine roots in the dry zone vegetations of Sri Lanka.

\section{Materials and Methods}

\subsection{Study sites}

Representative sampling sites were selected from a dry zone forest (Sigiriya sanctuary) and a dry zone arboretum of Sri Lanka. The arboretum, which represents a dry-mixed evergreen forest (Cramer, 1993) was selected, because we were interested to know how close a silviculturally-managed forest to a natural forest for supporting $\mathrm{C}$ sequestration. Although, a natural forest corresponds to an old growth forest, a silviculturally managed forest also represents a closed canopy with high species composition similar to a natural forest (Cramer, 1993; Perera, 2001; Dilhan, 2006).Thus, we assumed that the light penetration to the forest floor and soil temperature between the two sites are comparable. It is reported that fine root growth is governed by soil temperature when it fluctuates sharply during day and night with night temperatures below $17{ }^{\circ} \mathrm{C}$, but soil moisture becomes the determinant factor above that temperature (Teskey and Hinekley, 1981; Pregitzer et al., 2000). Thus, in dry tropical forests in general, soil moisture is considered to be the determinant of fine root growth (Yavitt and Wright, 2001).

Study sites with similar slope (almost flat terrain at $185-215 \mathrm{~m}$ elevation) were selected from both sites. The sanctuary surrounds the ancient rock fortress of Sigiriya, an archeologically important world heritage site at $150 \mathrm{~m}$ altitude. In the 1990's, it was declared a sanctuary with 5,099 hectares (Green, 1990). It is composed of understory plants $(<10 \mathrm{~cm} \mathrm{DBH})$ of 81 species representing 73 genera and 37 families (Solangaarachchi and Perera, 1993). The canopy of the forest is somewhat discontinuous and approximately $15-18 \mathrm{~m}$ in height. Sigiriya sanctuary is a secondary naturalized forest due to "Swidden" agriculture (Perera, 2001). The initial soil properties of Sigiriya sanctuary were recorded during the dry spell of 2007 by Kuruppuarachchi (2011) as, soil temperature $\left(25-32{ }^{\circ} \mathrm{C}\right)$, moisture $(10.04 \% \pm 4.5), \mathrm{pH}(6.19 \pm 0.38)$, soil organic carbon $(1.48 \% \pm 0.25)$, total $\mathrm{N}(0.10 \% \pm 0.02), \mathrm{NH}_{4}{ }^{+}-\mathrm{N}$ $(0.03 \mu \mathrm{g} / \mathrm{g}$ soil \pm 0.01$), \mathrm{NO}_{3}{ }^{-} \mathrm{N}(0.182 \mu \mathrm{g} / \mathrm{g}$ soil \pm 0.01$)$, and bulk density $\left(1.40 \mathrm{~g} / \mathrm{cm}^{3} \pm 0.28\right)$.

The arboretum $\left(5^{\circ} 54^{\prime} \mathrm{N}-9^{\circ} 52^{\prime} \mathrm{N}\right.$ and $\left.79^{\circ} 39^{\prime} \mathrm{E}-81^{\circ} 53^{\prime} \mathrm{E}\right)$ is situated in Dambulla, which is located in the dry heartland of Sri Lanka. This is the only dry zone arboretum in Sri Lanka that is used as a living museum, a shelter for tropical trees that provides refuge for wildlife (Dilhan et al., 2010). The arboretum was silviculturaly managed to form a natural forest. The arboretum is covered by different vegetation types such as dry mixed evergreen forest, woodland, and scrubland. The variety of habitats contributes to increased biodiversity of the arboretum, comprising 192 plant species, 72 bird species and 
35 types of butterflies (Cramer, 1993; Dilhan et al., 2010). The initial soil properties of the arboretum were recorded during the dry spell of 2007 by Kuruppuarachchi $(2011)$ as, soil temperature $\left(25-32{ }^{\circ} \mathrm{C}\right)$, moisture $(10.22 \% \pm 1.16), \mathrm{pH}(6.26 \pm 0.04)$, soil organic carbon $(1.40 \% \pm 0.05)$, total $\mathrm{N}(0.10 \% \pm$ $0.005), \mathrm{NH}_{4}{ }^{+}-\mathrm{N}(0.03 \mu \mathrm{g} / \mathrm{g}$ soil \pm 0.04$), \mathrm{NO}_{3}{ }^{-}-\mathrm{N}(0.16 \mu \mathrm{g} / \mathrm{g}$ soil \pm 0.05$)$, and bulk density $\left(1.36 \mathrm{~g} / \mathrm{cm}^{3} \pm\right.$ $0.15)$.

\subsection{Sampling}

A plot of $20 \mathrm{~m}$ x $20 \mathrm{~m}$ was demarcated in the two sites for sampling. Monthly, twenty soil core samples, to a depth of $25 \mathrm{~cm}$, were taken randomly to cover a whole annual cycle from January to December 2007. Then, the samples were air dried and sieved $(<2 \mathrm{~mm})$. Fine roots $(\leq 2 \mathrm{~mm}$ diameter $)$ on the sieve were handpicked. Fine roots in $<2 \mathrm{~mm}$ soil fraction were collected using a magnifying glass. Very fine root fraction was separated by the water floating technique (Anderson and Ingram, 1998). Then, all the fine root fractions were amalgamated and oven dried at $60{ }^{\circ} \mathrm{C}$ to a constant weight (Hodge et al., 2000). Total fine root biomass was calculated as a percentage of soil weight using the following equation. Density of fine root biomass was calculated as root weight per square meter using soil bulk density, and C density was considered as $50 \%$ of fine root density (IPCC, 2006). Fine root biomass and C density were expressed as weight in tons per hectare.

\section{Fine root biomass $(\%)=\left(\right.$ Oven-dried fine root weight/Oven-dried $\left(105^{\circ} \mathrm{C}\right)$ soil weight $) \times 100$}

Fourier transform infrared spectroscopy (FTIR) spectra were obtained of KBr pellets, formed by the dried soil samples with $\mathrm{KBr} 1$ to 50 ratios. The pellet was analyzed under $4000-400 \mathrm{~cm}^{-1}$ wave number range with a resolution of $4 \mathrm{~cm}^{-1}$. Each spectrum was composed of 64 scans coded before Fourier transforms processing. The OMNIC ${ }^{\complement}$ version 6.1 - windows (Thermo Nicolete Corp.) on the reduced

portions of the spectra $\left(4000-400 \mathrm{~cm}^{-1}\right)$ was used. FTIR peaks representing different chemical bonds of active groups in natural molecules were identified using the software and literature (Lammers et al., 2009; Celi et al., 2010).

\section{Results and Discussion}

Annual mean fine root biomass of the dry zone forest and the arboretum were found to be $5.72 \pm$ $0.57 \mathrm{t} / \mathrm{ha}(2.69 \pm 0.27 \mathrm{tC} / \mathrm{ha}), 7.88 \pm 0.81 \mathrm{t} / \mathrm{ha}(3.70 \pm 0.38 \mathrm{tC} / \mathrm{ha})$, respectively. The average standing fine root biomass $(0-50 \mathrm{~cm}$ depth) in global tropical forests has been reported to be $4.51 \pm 0.45 \mathrm{t} / \mathrm{ha}$ (Hertel and Leuschner, 2005), and it increases with the altitude (Cairns et al., 1997). However, in Amazonian forests, fine root growth up to $8.06 \mathrm{t} / \mathrm{ha}$ has been reported (Cuevas and Medina, 1988), which is comparable with our study. Generally, root biomass can differ largely between stands depending on tree species, soil conditions, and profile depth. The higher fine root growth, particularly in the arboretum, may be due to silvicultural management of the site, which has contributed to comparatively higher fine root $\mathrm{C}$ sequestration.

Maximum fine root growth was observed during the dry spell in August in both sites (Fig. 1). This allows the trees to absorb more water from water stressed soil. Nutrients required to grow the roots during the drought were likely supplied from the decomposition of soil labile $\mathrm{C}$, as reflected by the reduction of the $\mathrm{C}$ fraction (aliphatic $\mathrm{C}-\mathrm{H}$ vibration peaks at $2924 \mathrm{~cm}^{-1}$ ) in the FTIR spectral data (Fig. 2). With the commencement of rain in September, the root biomass started to drop sharply due to decomposition in the dry zone forest, but not in the arboretum. Fresh $\mathrm{C}$ leaching to the sub soil from the decomposing fine roots, as well as the floor litter layer (Fontaine et al., 2007) during the rainy period of the dry zone forest, has apparently contributed to the decomposition of stable $\mathrm{C}$ fractions (aromatic $\mathrm{C}-\mathrm{H}$, vibration peaks at $1618 \mathrm{~cm}^{-1}$ and $3414 \mathrm{~cm}^{-1}$ ), as evident from the FTIR spectral data. In January, there was a relatively high fine root biomass in the arboretum compared to the dry zone forest. 
Kuruppuarachchi, et al. /Journal of Tropical Forestry and Environment Vol. 3, No. 01 (2012) 20-26

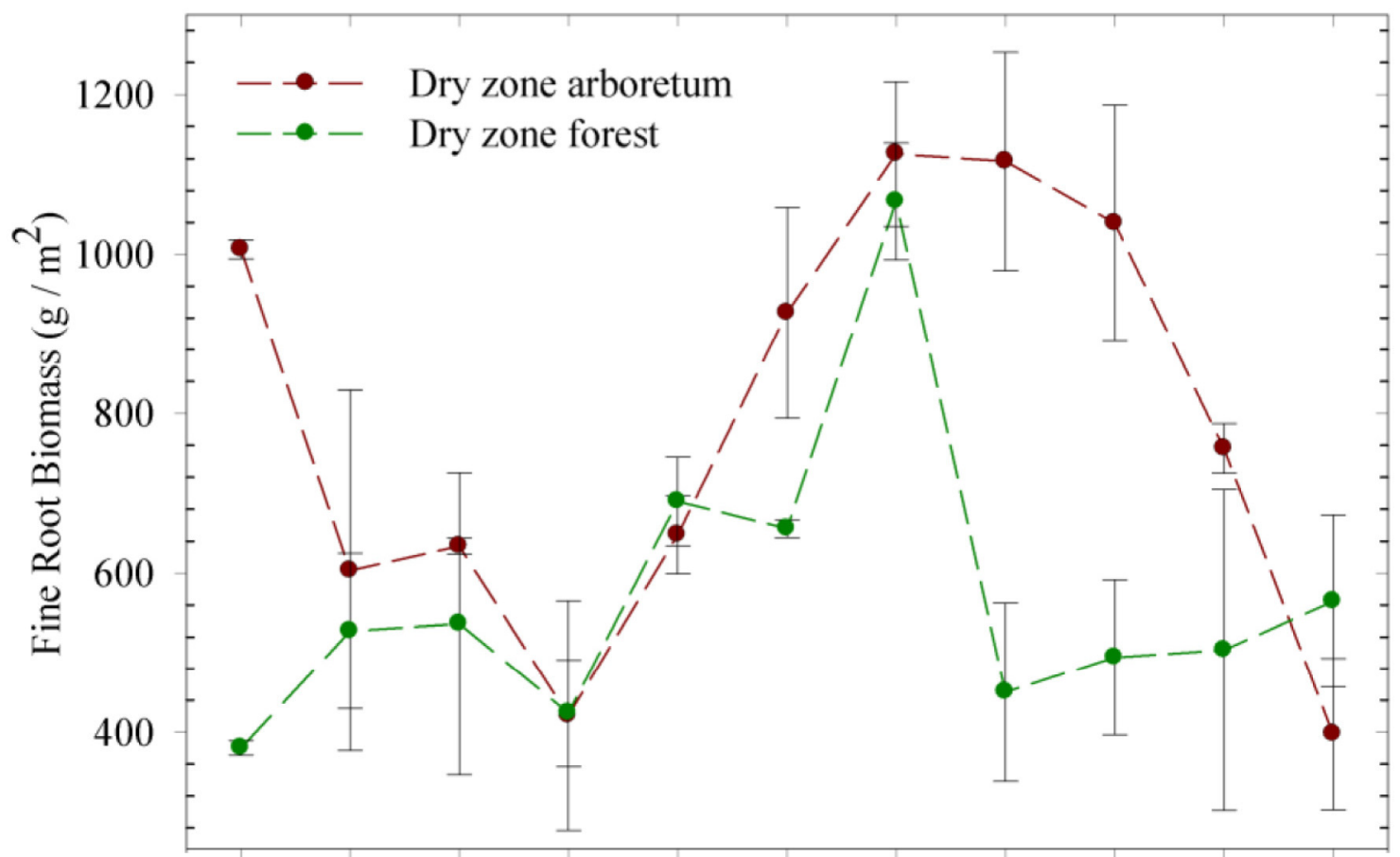

Jan. Feb. Mar. Apr. May Jul. Aug. Sep. Oct. Nov. Dec.

Month

Figure 1: Fine root biomass dynamics of the dry zone forest and the arboretum during January to December 2010. Vertical bars show standard errors.

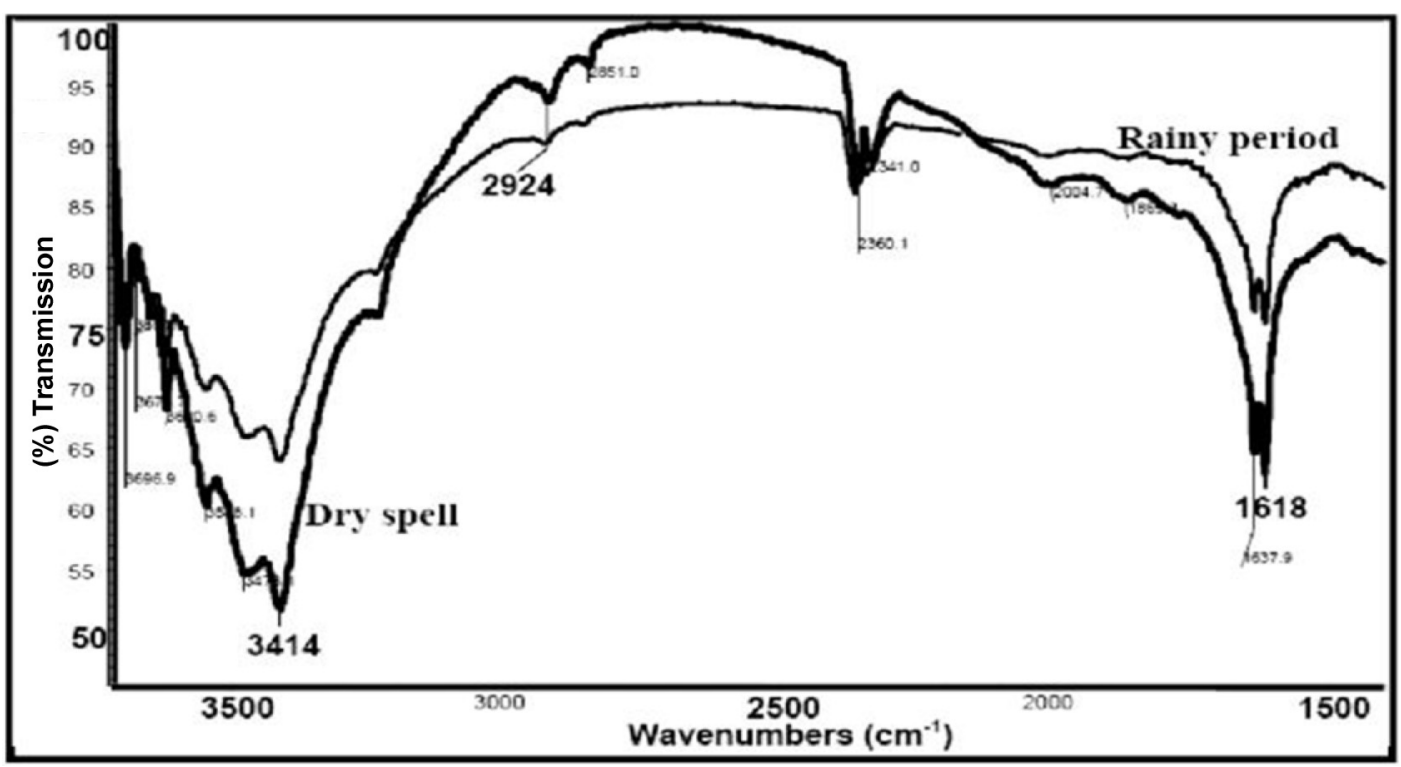

Figure 2: FTIR spectra of soils collected during dry and rainy periods of the dry zone forest. Thick and thin lines of the spectrum represent dry and rainy periods, respectively. $\% \mathrm{~T}$ is the percentage transmittance.

The fine roots occurring mainly in the upper soil horizons represent the most dynamic part of the root system (Cairns et al., 1997). Roots can respond to both internal and external controls such as 
temperature and water availability. Fine root longevity depends on species, climate, and soil conditions and can range from weeks to several years. However, factors controlling root dynamics are still poorly understood (Hendrick and Pregitzer, 1996).

From the satellite data, it was observed that there was a leaf flush with canopy green-up in the dry zone forest (Figure 3).However, in the arboretum a leaf flush was not visible due to small size of the site. An unusual above ground leaf flush has also been observed in Amazon forests in an extreme drought (Berlin et al., 2000; Saleska et al., 2007). Pau et al. (2010) have also identified Hawaiian rainforest greenup in responses to seasonal and El Niño-driven droughts. Nutrients required to grow the canopy during the drought may also have been supplied from the soil labile $\mathrm{C}$ decomposition, as mentioned above.

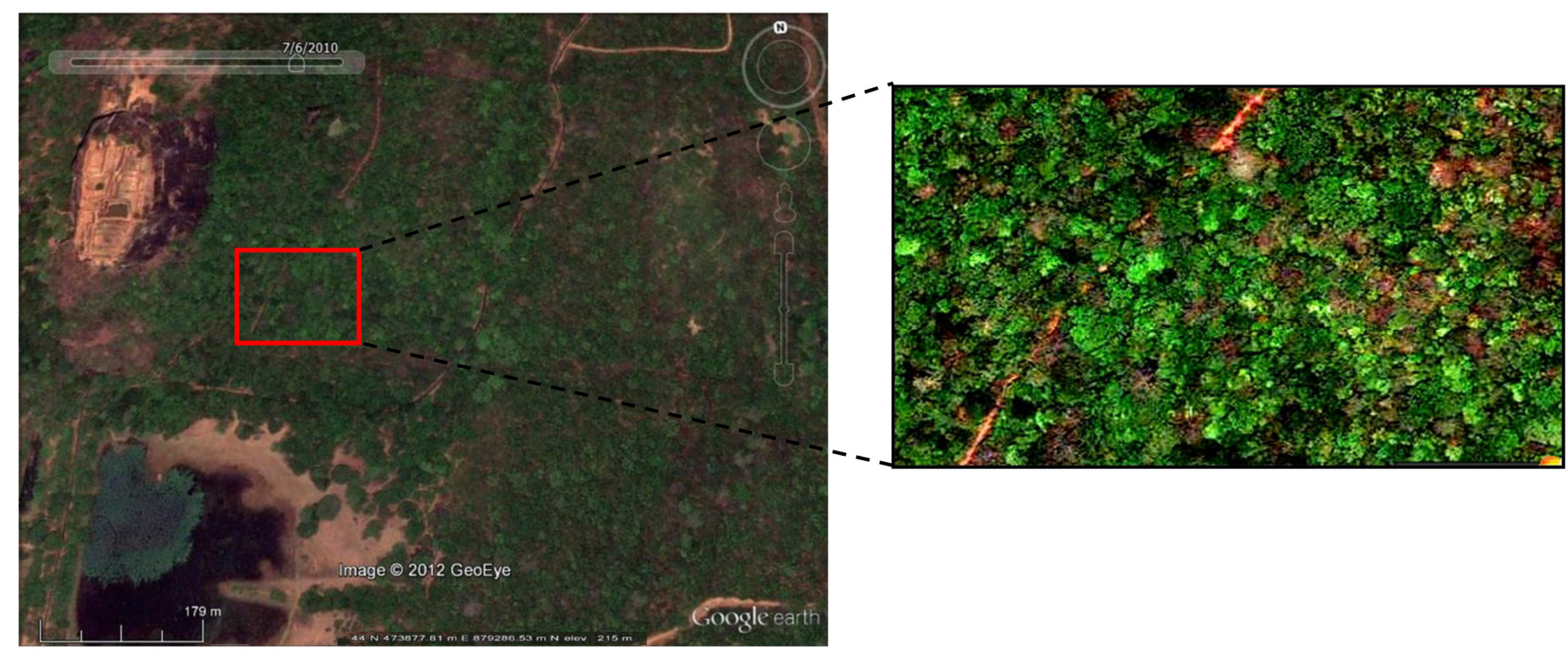

Figure 3: Canopy of the Sigiriya dry zone forest during the dry spell. Light green color patches on the canopy are the new flush. High spatial resolution images were acquired from Google Maps and Google Earth (Source: http://maps.google.com).

\section{References}

Anderson, J.M., and Ingram, J.S.I. 1998. Tropical Soil Biology and Fertility: A handbook of methods, second ed. CABI international, UK.

Berlin, K.E., Pratt, T.K., Simon, J.C., Kowalsky, J. R., and Hatfield, J.S. 2000. Plant phenology in a cloud forest on the island of Maui. Biotropica 32: 90-99.

Cairns, M.A., Brown, S., Helmer, E.H., and Baumgardner, G.A. 1997. Root biomass allocation in the word upland forests. Oecologia 111: 1-11.

Celi, L., Rosso, F., Freppaz, M., Agnelli, A., and Zanini, E. 2010. Soil organic matter characteristics in sporadic permafrost-affected environment (Creux du Van, Switzerland). Arctic, Antarctic, and Alpine Research 42:1-8.

Cramer, L.H. 1993. A forest arboretum in the dry zone. Institute of Fundamental Studies, Kandy, Sri Lanka.

Cuevas, E., and Medina, E. 1988. Nutrient dynamics within Amazonian forests. II. Fine root growth, nutrient availability and leaf litter decomposition. Oecologia 76: 222-235.

Dilhan, M.A.A.B., Amarasinghe, J., and Wijewardene, D.N.N. 2010. Building sustainable botanic gardens: a simple silvicultural method adopted to haven certain wood trees into productive arboretum in the dry zone of Sri Lanka.Proceedings of the Fourth Global Botanic Gardens Congress, Dublin, 
Ireland, 1-4. http://www.bgci.org/files/Dublin2010/papers/Dilhan-M-A-A-B.pdf. Access 01 December 2010.

Dilhan, M.A.A.B., Weerasinghe, T.D. and Amarasinghe, J. 2006. Structure and composition of vegetation in the IFS - Popham arboretum, Dambulla. WildLanka 1:90-102.

Dittus, W.P.J. 1985. The influence of leaf-monkeys on their feeding trees in a cyclone-disturbed environment. Biotropica 17: 100-106.

Fontaine, S., Barot, S., Barré, P., Bdioui, N., Mary, B., and Rumpel, C. 2007. Stability of organic carbon in deep soil layers controlled by fresh carbon supply. Nature 450: 277-280.

Green, M.J.B. 1990. IUCN Directory of South Asian Protcted areas. IUCN, Cambridge, U.K.

Hendrick, R.L., and Pregitzer, K.S. 1996. Applications of minirhizotrons to understand root function in forests and other natural ecosystems. Plant and Soil 185: 293-304.

Hertel, D., and Leuschner, C.H. 2005. Fine root mass and fine root production at tropical moist forests as dependent on soil, climate and elevation. In: Bruijnzeel, L.A., and Juvik, J. (Eds.), Mountains in the mist: Science for conserving and managing tropical Montane cloud forests, Hawaii University press, pp. 208-216.

Hodge, A., Stewart, J., Robinson, D., and Fitter, A.H. 2000. Competition between roots and soil microorganisms for nutrients from nitrogen-rich patches of varying complexity. Journal of Ecology 88: 150-164.

IPCC, 2006. IPCC Guidelines for National Greenhouse Gas Inventories. In: Eggleston, H.S, Buendia, L., Miwa, K., Ngara, T. and Tanabe, K. (Eds.), Prepared by the National Greenhouse Gas Inventories Programme, Institute for Global Environmental Strategies, IPPCC, Hayama, Japan.

Jackson, R.B., Mooney, H.A., and Schulze, E.D. 1997. A global budget for fine root biomass, surface area, and nutrient contents. Proceedings of the National Academy of Sciences 94: 7362-7366.

Kuruppuarachchi, K.A.J.M. 2011. Carbon sequestration as influenced by climatic, plant and soil parameters, their dynamics and control of selected Sri Lankan forests. Doctor of Philosophy Dissertation, Faculty of Natural Sciences, The Open University of Sri Lanka.

Lammers, K., Arbuckle-Keil, G., and Dighton J. 2009. FTIR study of the changes in carbohydrate chemistry of three New Jersey Pine Barrens leaf litters during simulated control burning. Soil Biology and Biochemistry 41: 334-340.

Nespstad, D.C., Carvalho, C., Davidson, E., Jipp, P.H., Lefebvre, P., Negreiros, G.H., Da Silva, E.D., Stone, T.A., Trumbore, S.E., and Vieira, S.A. 1994. The role of deep roots in the hydrological and carbon cycles of Amazonian forests and pastures. Nature 372: 666-669.

Pau, S., Okin, G.S., and Gillespie, T.W. 2010. Asynchronous response of tropical forest leaf phenology to seasonal and El Niño-Driven Drought. PLoS ONE 5(6): e11325. doi:10.1371 /journal.pone.0011325.

Perera, G.A.D. 2001. The secondary forest situation in Sri Lanka: A Review. Journal of Tropical Forest Science 13: 768-785.

Pregitzer, K.S., King, J.S., Burton, A.J., and Brown, S.E. 2000. Response of tree fine roots to temperature. New Phytologist 147: 105-115.

Pregitzer, K.S., 2002. Fine roots of trees - a new perspective. New Phytologist 154: 267-270.

Rasse, D.P., Rumpel, C., and Dignac, M.F. 2005. Is soil carbon mostly root carbon? Mechanisms for a specific stabilization. Plant and Soil 269: 341-356.

Saleska, S.R., Didian, K., Huete, A.R., and Da Rocha, H.R. 2007. Amazon forests green-up during 2005 drought. Science318(5850): 612.

Seneviratne, G., Kuruppuarachchi, K.A.J.M., Somaratne, S., and Seneviratne, K.A.C.N. 2006. Nutrient cycling and safety-net mechanism in the tropical Home gardens. International Journal of Agricultural Research 1: 169-182.

Solangaarachchi, S.M., and Perera, B.M.S. 1993. Floristic composition and medicinally important plants in the understory of the tropical dry mixed evergreen forest at the Hurulu reserve of Sri Lanka. Journal of National Science Council Sri Lanka 21(2): 209-226. 
Teskey, R.O., and Hinekley, T.M. 1981. Influence of temperature and water potential on root growth of whiteoak. Physiologia Plantarum 52: 363-369.

Upadhaya, K., Pandey, H.N., Law, P.S., and Tripathi, R.S. 2005. Dynamics of fine and coarse roots and nitrogen mineralization in a humid subtropical forest ecosystem of northeast India. Biology and Fertility of Soils 41: 144-152.

Vargas, R., and Allen, M.F. 2008. Dynamics of fine root, fungal rhizomorphs, and soil respiration in a mixed temperate forest: Integrating sensors and observations. Vadose Zone Journal 7: 1055-1064.

Yavitt, J. B., and Wright, S.J. 2001. Drought and irrigation effects on fine root dynamics in a tropical moist forest, Panama. Biotropica 33: 421-434. 